\title{
Soil chemical characteristics in wet and dry season at Iva long wall underground mined site, Nigeria
}

\author{
Ogbonna, P.C. ${ }^{1, *}$, Nzegbule, E.C. ${ }^{1}$ and Okorie, P.E. ${ }^{2}$ \\ ${ }^{1}$ Department of Environmental Management and Toxicology, Michael Okpara University of Agriculture, \\ Umudike, PMB 7267 Umuahia, Abia State, Nigeria \\ ${ }^{2}$ Department of Forestry and Environmental Management, Michael Okpara University of Agriculture, Umudike \\ P.M.B. 7267 Umuahia, Abia State, Nigeria \\ Corresponding Author: *ogbonna_princewill@yahoo.com
}

\begin{abstract}
In a bid to diversify the sources of revenue generation in Nigeria, the Government of the Federation has initiated plans to resuscitate coal mining. This study, therefore, assessed the impact of previous mining activities on soil chemical characteristic of the abandoned site. A single factor experiment was conducted in a randomized complete block design (RCBD) with three replications to obtain information on soil status of Iva mined site. Soil samples were collected randomly from ten different sampling points at 0-10, 10-20, and 20-30 cm soil depth in four cardinal points at north $(N)$, south (S), east (E), west (W), and at the centre (c) of crest, middle slope, and valley of Iva mined site. The samples were analysed for heavy metals, macronutrient, soil $\mathrm{pH}$, and organic matter content. The organic matter values ranged from $0.00 \pm 0.00$ to $1.14 \pm 0.02 \%$ in dry season and $0.00 \pm 0.00$ to $1.04 \pm 0.06 \%$ in wet season, with higher levels of organic matter in the valley $(\mathrm{OM} \leq 1.14 \%)$. Soil $\mathrm{pH}$ values ranged from 3.98 to 6.00 in wet season and 3.82 to 5.34 in dry season, with higher levels of acidity in the middle slope $(\mathrm{pH} \leq 4.37)$. The range of values of soil macronutrients $(\mathrm{K}, \mathrm{Mg}, \mathrm{N}$ and $\mathrm{P})$ were higher in wet season than in dry season with higher levels of $\mathrm{K}, \mathrm{Mg}, \mathrm{N}$ and $\mathrm{P}$, at middle slope. Similarly, the values of the concentration of heavy metals (Ni and $\mathrm{Pb}$ ) in soil were higher in wet season than in dry season with higher levels of $\mathrm{Ni}$ and $\mathrm{Pb}$ at middle slope. The levels of $\mathrm{Ni}, \mathrm{Pb}$ and $\mathrm{Cd}$ in this study are above their allowable limits in Austria, Germany, France, Netherlands, Sweden, and United Kingdom. The high concentrations of Cd and $\mathrm{Ni}$ in soils could be taken up in plants via the roots, thus, exposing both man and herbivores to serious health risks.
\end{abstract}

Keywords: Chemical characteristics, soil, dry, Iva mine, wet

\subsection{Introduction}

The demand for coal increased when coke made from bituminous coal began replacing charcoal in the iron ore smelting industries (Brown and Dey, 1975). Coal contains a significant amount of pyrites, and exposure of pyrite to atmospheric oxygen through mining activities causes its oxidation to ferrous sulphate and sulphuric acid in the presence of bacteria. The suphuric acid formed lowers the $\mathrm{pH}$ of the soil and water, which affects the populations and activities of organisms inhabiting these environments (Sarma, 2002).

Mining activities have adversely affected the physical environment causing massive damage to landscape and biological communities, and contaminating soil and water with the associated metals (Ademoroti, 1996). Heavy metal (HM) pollution is a world-wide phenomenon that poses serious health hazards to aquatic and terrestrial ecosystems. In Guizhou Province of Southwest China, millions of inhabitants were badly affected with dental and skeletal fluorosis as well as arsenic poisoning due to heavy metals released during the burning of mineralized coal (Finkelman, 2007). More so, fluorine emitted from domestic use of coal was responsible for the fluorosis being suffered by thousands of people in China (Ando et al., 1998). 
Soil chemical properties and soil life have possibilities of being modified by the mining activities. Like any fossil fuel, coal is associated with naturally occurring radioactive materials due to their ${ }^{238} \mathrm{U}$, ${ }^{232} \mathrm{Th}$, and ${ }^{40} \mathrm{~K}$ content, which certainly has radiological implications not only for the miners but also for the populace in the immediate environment of the mines and the users (Balogun et al., 2003). Presently, moves are being made in Nigeria by the Federal government to resuscitate coal mining (National Mirror 28 Feb. 2013; The Tide 28 Feb. 2013), thus, it is necessary to know the outcome of previous activities on the environment for necessary precaution. There is presently inadequate knowledge on the impact of coal mining on soil chemical characteristics of soils at coal mine sites in Nigeria. This, therefore, warrants the investigation on the soil quality in the vicinity of Iva coalmine in Enugu, Enugu State.

\subsection{Materials and Methods}

\subsection{Study area}

The study area consisted of very large deposits of sub-bituminous coal, estimated at 1.5 million tons that have been mined since 1916 (Diala, 1984). It lies within latitude $6^{\circ} 23^{\prime}$ and $6^{\circ} 26^{\prime} \mathrm{N}$ and longitude $7^{\circ} 27^{\prime}$ and $7^{\circ} 30^{\prime} \mathrm{E}$, and the mean monthly temperature lies between 27 and $29^{\circ} \mathrm{C}$ (Ekere and Ukoha, 2013). The climate is influenced by South-westerly winds that bring rains from April to October, while the Northeast trade winds are responsible for the harmattan with low humidity from December to February. On the average, about $70 \%$ of the total land area of Iva support agriculture, and the food and cash crops produced by farmers include yam, maize, ogbono (Irvingia gabonensis var excelsa), melon, cassava, local beans, oil palm, rice, groundnut, and cocoa. The major streams/rivers in Enugu include the Ekulu, Ogbete and Nyaba rivers. Most streams in the area are not perennial but dry up during the late part of the dry season. Some perennial streams rise from the middle levels of the escarpment near the base of the Ajali sandstone.

\subsection{Soil collection and analysis}

Prior to the sample collection, a reconnaissance survey was carried out to determine the altitude of Iva mined site, which is $259 \mathrm{~m}$. Soil samples were collected in February for dry season and June for wet season from Iva mine and control site. Soil samples were collected randomly from ten different sampling points at 0-10,10-20, and 20-30 cm soil depth with Dutch soil auger in four cardinal points (i.e. two sampling points each at north $(\mathrm{N})$, south $(\mathrm{S})$, east $(\mathrm{E})$, west $(\mathrm{W})$, and at the centre $(\mathrm{C})$ of crest, middle slope and valley of the Iva mined site. The control sample was collected in a 5 year upland bush fallow about $2 \mathrm{~km}$ from the mined sites where there was no visible source of contamination. Samples from each particular soil depth (e.g., 0-10 cm at N, S, E, W, and C) were placed in cellophane bags (about $25 \mathrm{~g}$ ), well labelled, placed in a wooden box and covered to avoid contamination from external sources. The samples in the wooden box were transferred to the laboratory for pre-treatment and analysis. Samples from the same soil depth were bulked together to give a composite sample which were homogenized and air-dried in a circulating air in the oven at $30^{\circ} \mathrm{C}$ to a constant weight and passed through a $2 \mathrm{~mm}$ sieve.

\subsection{Analysis of heavy metal in soil}

Sub-samples from the composite samples were digested according to the method of Shriadah (1999). To $5 \mathrm{~g}$ of each soil sample was added $3 \mathrm{ml}$ of $30 \%$ hydrogen peroxide, which was left to stand for 60 mins until vigorous reaction ceased. Then $75 \mathrm{ml}$ of $0.5 \mathrm{M}$ solution of $\mathrm{HCl}$ was added and content heated gently at $50^{\circ} \mathrm{C}$ on hot plate for $2 \mathrm{~h}$. The digest was filtered into $50 \mathrm{~mL}$ standard flask. The hydrogen peroxide and hydrogen chloride acid used were of analytical grade and were manufactured by Merck KgaA (Darmstadt, Germany). The concentrations of $\mathrm{Ni}, \mathrm{Pb}, \mathrm{Cd}$, As, and $\mathrm{Fe}$ in the digested samples were determined using flame Atomic Absorption Spectrophotometer (UNICAM 919 model) after calibrating the equipment with different standard concentrations as follows: Cd: $0.5,1$, and 2 ppm, Pb: 1, 5, 10 ppm , Ni: 2, 5, 10 ppm, Fe: 1, 2, 5 ppm, and As: 1, 4, 8 ppm. The calibration curves were prepared from standards by dissolving appropriate amounts of the metal salts in purified nitric acid, diluting with deionized water and storing as stock solutions in a quartz flask. Fresh working solutions were obtained by serial dilution of stock solutions. Quality control was implemented through three replicate samples, reagent blank, spiking and use of international soil reference sample (SRM 989, The Netherlands). 


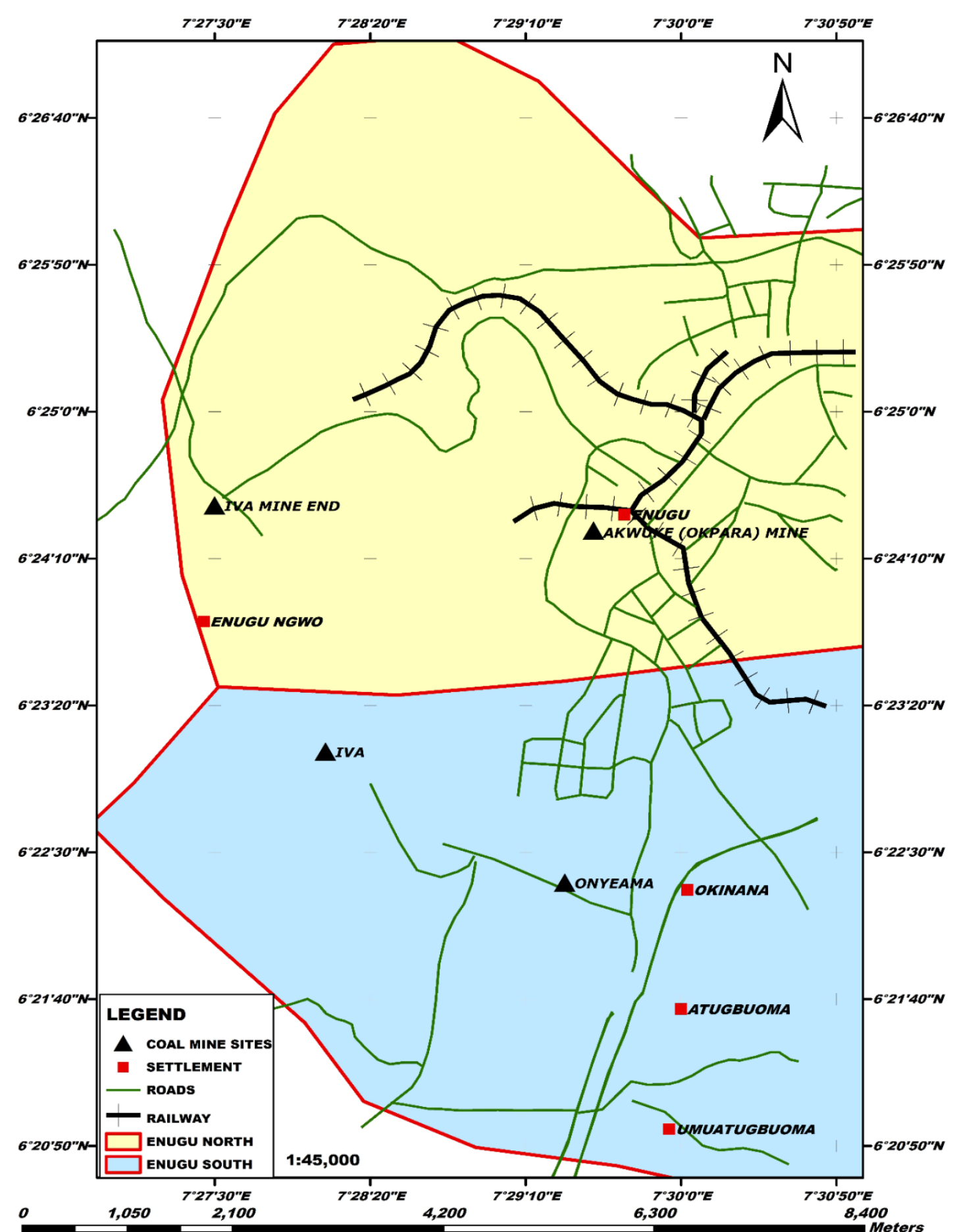

Figure 1: Map of study area

Measurements were made using the hollow cathode lamps for $\mathrm{Cd}, \mathrm{Pb}, \mathrm{Ni}, \mathrm{Fe}$, and $\mathrm{As}$ at the proper wavelength and the slit width were adjusted and other AAS conditions were employed in these determinations. The flame type used for all elements was air-acetylene. Working solutions were prepared by dilution. For the determination, two solutions were prepared for each sample and three separate readings were made for each solution. The mean of these figures were used to calculate the concentrations. Triplicate digestion of each sample was carried out together with blank digest without the plant sample. Distilled-deionized water was prepared by passing distilled water through a Milli-Q reagent grade water system.

\subsection{Macro element content}

For macro-element determination, sieved soil samples were digested according to the wet digestion method of Novozamsky et al. (1983). Ca and Mg in the digest were determined by EDTA titration 
method, $\mathrm{K}$ and $\mathrm{P}$ was determined by flame photometry while total $\mathrm{N}$ was extracted by sulphur digestion and determined by the micro-Kjeldahl method (Nelson and Sommers, 1972).

\subsection{Determination of soil organic matter}

Organic matter levels in the air dried soils were estimated indirectly from organic carbon. Organic carbon was determined by oxidation of organic matter with a hot mixture of $\mathrm{K}_{2} \mathrm{Cr}_{2} \mathrm{O}_{7}$ and $\mathrm{H}_{2} \mathrm{SO}_{4}$ using the Walkley and Black procedure (Walkley and Black, 1934). The amount of organic carbon was then determined by titration with $0.05 \mathrm{~N} \mathrm{FeSO}_{4}$ following the procedure outlined by Nelson and Sommers (1982). The organic matter content was obtained by multiplying the organic carbon content with the factor 1.729 (Nelson and Sommers, 1982).

\subsection{Determination of soil $\mathrm{pH}$}

In soil $\mathrm{pH}$ determination, soil samples were weighed and mixed with distilled water in the water to soil ratio of 2.5:1 (Lu, 1999; Nartey et al., 2012) in the laboratory. Thereafter, soil pH was measured using $\mathrm{pH}$ meter DEMO 13702.93 manufactured by PHYWE of Germany.

\subsection{Experimental design and data analysis}

A single factor experiment was conducted in a randomized complete block design (RCBD) with 3 replications. Data collected on socio-economic variables was analysed with descriptive analysis while data on impact of mining on soil, plant and soil fauna were subjected to a 2-way analysis of variance (ANOVA) using special package for social sciences (SPSS) v. 15 and means were separated (Steel and Torrie, 1980) at $\mathrm{P}<0.05$ using Duncan New Multiple Range Test (DNMRT).

\subsection{Results and Discussion}

\subsection{Soil chemical characteristics of the experimental site}

The results on soil $\mathrm{pH}$, macronutrient, and soil organic matter content in soil at Iva mined site in wet and dry season is summarized in Table 1. The results indicate that the highest and the lowest values of soil $\mathrm{pH}$ were obtained at the control site and the mined site, respectively. The higher soil $\mathrm{pH}$ values at the control site may be attributed to the release of higher basic cations during organic matter decomposition (Oyedele et al., 2008) since there was no mining activity at the control site. The $\mathrm{pH}$ of the control site ranged from 5.90 - 6.55 which is higher than $3.82-6.00$ recorded at Iva mine site. The Iva mine site was more acidic than the control site. The high acidic nature of the mined site may be attributed to flushes of acid mine drainage at the mine site. Soil pH ranged from $3.98-6.00$ in wet season and $3.82-5.34$ in dry season. Consequently, soil acidity was higher in dry season than in wet season, and this may be attributed to the dilution effect of rainfall. Soil $\mathrm{pH}$ was strongly acidic at middle slope (3.96) than crest (4.12) and valley (4.68) at Iva mine site. Generally, most metals do not exist in free form in the $\mathrm{pH}$ range of 6.0 - 9.0 (Porteus, 1985; Adie and Etim, 2012). The $\mathrm{pH}$ for all middle slope samples analysed in this study fell well below this range (Table 1). It therefore implies there would be high leaching of metals from the topsoil of the middle slope towards subsoil and subsequently the aquifer as most of the metals would be dissolved in solution. Lower $\mathrm{pH}$ increase the solubility of metals (Gabriella and Anton, 2005) and this may have contributed to the higher concentration of heavy metals in middle slope of Iva mine site (Table 2).

The highest organic matter contents in soil were observed at the control site. The low organic matter in soil at the mined site was as a result of mining activities. Mining involves the removal of topsoil and subsoil which destroys many plant species (Down, 1974), thus, reducing the build-up of organic matter on the site. The results also indicate that organic matter content in soil was higher in dry season than in wet season (Table 1). This is attributed to leaching effect of rainfall in wet season. Erosive activities in the agro-ecology of south-eastern Nigeria have contributed to decline in organic matter in soil (Mbagwu and Obi, 2003). The highest content of organic matter in soil at the mined site was recorded in dry season at $0-10 \mathrm{~cm}$ valley $(1.14+0.02 \%)$ of Iva mine (Table 1). Organic matter content decreases with soil depth (Agboola and Fagbenro, 1985; Omenihu and Ojimgba, 2008) since the abundance and activity of microorganisms decline with soil depth (Andersen and Domsche, 1989; Ekklund et al., 2001; Taylor et al., 2002; Fang et al., 2005). The magnitude of decline in organic matter content with depth in this study varied amongst sampling locations (crest, middle slope, and 
valley) but the rate of decline were highest in valley, followed by middle slope, and lastly crest. The range of organic matter content for the surface soils at Iva mine $(0.06+0.01$ to $1.14+0.02 \%)$ is lower than $0.86-9.98 \%$ reported for surface soils in Niger Delta, Nigeria (Ugiomoh and Anyanwu, 2016).

The highest content of macronutrients in soils was obtained at the control site (Table 1). Abandoned metalliferous mines are sites of extreme edaphic conditions characterized by low levels of essential soil nutrients (Bradshaw and Chadwick, 1980; Gibson and Risser, 1982) and mining activities alter the cycling of aboveground forest organic materials and their incorporation into the soil (Onweremadu et al., 2008). The value of $\mathrm{Ca}, \mathrm{Mg}, \mathrm{K}, \mathrm{N}$ and $\mathrm{P}$ at the control site was 19.30, 6.37, 12.48, 25.20, and $60.33 \%$ higher than the highest values recorded at Iva mine. These results corroborate the finding that macronutrient content in unpolluted soil is higher than the levels observed in metal contaminated soil (Ogbonna and Okezie, 2011). Among all the macronutrient investigated in soils at the mined site, $\mathrm{K}$ $(343.00 \pm 0.28 \mathrm{cmol} / \mathrm{kg}$ ) had the highest content in soils and this was obtained at $10-20 \mathrm{~cm}$ middle slope of Iva mine in wet season (Table 1). The value of $\mathrm{K}$ in soil during wet season ranged from 88.35 \pm 2.18 to $343.00 \pm 0.28 \mathrm{cmol} / \mathrm{kg}$, which is higher than $57.10 \pm 0.57$ to $212.00 \pm 0.57 \mathrm{cmol} / \mathrm{kg}$ observed in dry season. The value of $\mathrm{Mg}(319.40 \pm 0.85 \mathrm{cmol} / \mathrm{kg})$ in soil at the mined site was highest at 10-20 cm middle slope of Iva mine in wet season (Table 1). Mg in soil in wet season ranged from $78.00 \pm 0.57$ to $319.40 \pm 0.85 \mathrm{cmol} / \mathrm{kg}$, which is higher than $89.60 \pm 1.41$ to $251.90 \pm 1.41 \mathrm{cmol} / \mathrm{kg}$ observed in dry season. $\mathrm{N}(0.80 \pm 0.06 \mathrm{cmol} / \mathrm{kg})$ and $\mathrm{P}(1.42 \pm 0.06 \mathrm{cmol} / \mathrm{kg})$ in soil was highest at 20-30 cm middle slope of Iva mine in wet season. The mineralization of nitrogen and phosphorus from plant residues provides these nutrients ( $\mathrm{N}$ and $\mathrm{P}$ ) to the soil (Manzoni et al., 2010). The high content of $\mathrm{N}$ and $\mathrm{P}$ in 20-30 cm depth as well as $\mathrm{Mg}$ and $\mathrm{K}$ in 10-20 $\mathrm{cm}$ depth at Iva mine may be attributed to leaching effect of rainfall. This is in agreement with the findings of Asiegbu (1989) who reported that nitrogen is in short supply in south-eastern Nigeria because of leaching by rain and low organic matter content of the soil. Since these nutrients ( $\mathrm{Mg}, \mathrm{K}, \mathrm{N}$ and P) were observed to have peaked at the middle slope, leaching effect by rainfall may have accounted to the high macronutrient in soil (Table 1). In this study, the value of $\mathrm{N}$ in soil in wet season ranged from $0.06 \pm 0.03$ to $0.80 \pm$ $0.06 \mathrm{cmol} / \mathrm{kg}$, which is higher than $0.09 \pm 0.01$ to $0.36 \pm 0.03 \mathrm{cmol} / \mathrm{kg}$ observed in dry season; while the value of $P$ in soil in wet season ranged from $0.20 \pm 0.03$ to $1.42 \pm 0.06$, which is higher than 0.14 \pm 0.04 to $1.23 \pm 0.10$ observed in dry season. $\mathrm{Ca}(1.02 \pm 0.14$ to $8.12 \pm 0.14 \mathrm{cmol} / \mathrm{kg})$ in soil during the dry season is higher than $0.81 \pm 0.03$ to $6.83 \pm 0.10 \mathrm{cmol} / \mathrm{kg}$ in wet season. Calcium $(0.81 \pm 0.03$ to $8.12 \pm 0.14 \mathrm{cmol} / \mathrm{kg}$ ) in soil is higher than $1.86-2.10 \mathrm{mg} / \mathrm{kg}$ reported by Derome and Nieminen (1998) in their study on metal and macronutrient fluxes in heavy metal polluted scots pine ecosystems in SW Finland. The accumulation of heavy metals in soils can have long-term implications on biological, chemical and physical properties of soil (Nicholson et al., 2003). Generally, the values of $\mathrm{N}, \mathrm{P}, \mathrm{K}, \mathrm{Ca}$ and $\mathrm{Mg}$ in soil at Iva mine was higher in wet season than in dry season, and this may be attributed to rapid decomposition of organic material and subsequent mineralization of these macro elements in wet season. Indeed, the pattern of result is in the increasing order: $\mathrm{N}<\mathrm{P}<\mathrm{Ca}<\mathrm{Mg}<\mathrm{K}$.

Heavy metal concentrations in soils at mined and unmined (control) sites are summarized in Table 2. The comparisons in this study will be on the concentrations of the control soils (background soils) and concentrations in mined sites obtained in a number of research works globally and in other cities in Nigeria (Table 3) and allowable limits of some developed countries in the world (Table 4). The results indicate that the highest and the lowest metal concentrations in soil were observed at the mined site and control site, respectively. Soil concentrations of all metals except arsenic (As) were raised to different degrees in wet and dry season at the Iva mined site. The concentrations of heavy metal at the mined site were significantly raised compared to those at the control site, and significant differences was evidenced amongst the three sampling location (crest, middle slope and valley). The tailings dumped indiscriminately at mines can influence the natural concentrations of heavy metals in soil (Wong et al., 1998; Giachetti and Sabastiani, 2006). 
Table 1: Macronutrient ( $\mathrm{cmol} / \mathrm{kg})$, soil $\mathrm{pH}$ and organic matter $(\%)$ content in soil at Iva site in wet and dry season

\begin{tabular}{|c|c|c|c|c|c|c|c|c|c|}
\hline Location & Depth & Season & $\mathrm{Ca}$ & $\mathrm{Mg}$ & $\mathrm{K}$ & $\mathrm{N}$ & $\mathrm{P}$ & $\mathrm{pH}\left(\mathrm{H}_{2} \mathrm{O}\right)$ & $\mathrm{OM}(\%)$ \\
\hline \multirow{6}{*}{ Crest } & \multirow{2}{*}{$0-10 \mathrm{~cm}$} & Wet & $\begin{array}{l}6.83^{\mathrm{e}} \pm \\
0.10\end{array}$ & $\begin{array}{l}268.90^{c} \pm \\
12.87\end{array}$ & $\begin{array}{l}278.70^{\mathrm{d}} \pm \\
13.86\end{array}$ & $\begin{array}{l}0.14^{\mathrm{fgh}} \pm \\
0.03\end{array}$ & $\begin{array}{l}0.40^{\operatorname{lnn}} \pm \\
0.42\end{array}$ & $\begin{array}{l}4.12^{\mathrm{jk}} \pm \\
0.10\end{array}$ & $\begin{array}{l}0.86^{\mathrm{c}} \pm \\
0.05\end{array}$ \\
\hline & & Dry & $\begin{array}{l}1.05^{\mathrm{I}} \pm \\
0.14\end{array}$ & $\begin{array}{l}180.70^{\text {ef }} \\
\pm 1.70 \\
\end{array}$ & $\begin{array}{l}118.80^{\mathrm{ij}} \pm \\
1.84\end{array}$ & $\begin{array}{l}0.19^{\mathrm{e}-\mathrm{h}} \pm \\
0.03\end{array}$ & $\begin{array}{l}0.14^{\mathrm{n}} \pm \\
0.04\end{array}$ & $\begin{array}{l}4.82^{\mathrm{m}} \pm \\
0.08\end{array}$ & $\begin{array}{l}0.96^{\mathrm{c}} \pm \\
0.04\end{array}$ \\
\hline & \multirow{2}{*}{$10-20 \mathrm{~cm}$} & Wet & $\begin{array}{l}2.84^{\mathrm{j}} \pm \\
0.14\end{array}$ & $\begin{array}{l}248.90^{\mathrm{cd}} \\
\pm 1.84\end{array}$ & $\begin{array}{l}191.50^{\text {fgh }} \\
\pm 0.99\end{array}$ & $\begin{array}{l}0.09^{\mathrm{h}} \pm \\
0.01\end{array}$ & $\begin{array}{l}0.50^{\mathrm{k}-\mathrm{n}} \pm \\
0.10\end{array}$ & $\begin{array}{l}4.20^{\mathrm{ij}} \pm \\
0.03\end{array}$ & $\begin{array}{l}0.50^{\mathrm{de}} \pm \\
0.13\end{array}$ \\
\hline & & Dry & $\begin{array}{l}1.02^{1} \pm \\
0.14\end{array}$ & $\begin{array}{l}129.80^{\mathrm{g}} \pm \\
0.28\end{array}$ & $\begin{array}{l}97.50^{\mathrm{jk}} \pm \\
0.99\end{array}$ & $\begin{array}{l}0.13^{\text {fgh }} \pm \\
0.03\end{array}$ & $\begin{array}{l}0.62^{\mathrm{i}-\mathrm{m}} \pm \\
0.06\end{array}$ & $\begin{array}{l}4.07^{\mathrm{kl}} \pm \\
0.06\end{array}$ & $\begin{array}{l}0.57^{\mathrm{de}} \pm \\
0.07\end{array}$ \\
\hline & \multirow{2}{*}{$20-30 \mathrm{~cm}$} & Wet & $\begin{array}{l}3.86^{\mathrm{h}} \pm \\
0.06\end{array}$ & $\begin{array}{l}259.00^{\mathrm{cd}} \\
\pm 15.56\end{array}$ & $\begin{array}{l}230.10^{\text {ef }} \\
\pm 1.56\end{array}$ & $\begin{array}{l}0.07^{\mathrm{h}} \pm \\
0.01\end{array}$ & $\begin{array}{l}0.36^{\mathrm{mn}} \pm \\
0.08\end{array}$ & $\begin{array}{l}4.27^{\mathrm{hi}} \pm \\
0.07\end{array}$ & $\begin{array}{l}0.03^{\mathrm{g}} \pm \\
0.01\end{array}$ \\
\hline & & Dry & $\begin{array}{l}1.80^{\mathrm{k}} \pm \\
0.06\end{array}$ & $\begin{array}{l}130.70^{\mathrm{g}} \pm \\
1.56\end{array}$ & $\begin{array}{l}168.10^{\mathrm{gh}} \\
\pm 0.28\end{array}$ & $\begin{array}{l}0.26^{\mathrm{ef}} \pm \\
0.07\end{array}$ & $\begin{array}{l}0.38^{\operatorname{lnn}} \pm \\
0.13\end{array}$ & $\begin{array}{l}3.99^{\mathrm{kl}} \pm \\
0.01\end{array}$ & $\begin{array}{l}0.13^{\mathrm{g}} \pm \\
0.04\end{array}$ \\
\hline \multirow{6}{*}{$\begin{array}{l}\text { Middle } \\
\text { slope }\end{array}$} & \multirow{2}{*}{$0-10 \mathrm{~cm}$} & Wet & $\begin{array}{l}0.81^{1} \pm \\
0.03\end{array}$ & $\begin{array}{l}239.80^{\mathrm{d}} \pm \\
13.86\end{array}$ & $\begin{array}{l}192.60^{\mathrm{fgh}} \\
\pm 1.13\end{array}$ & $\begin{array}{l}0.06^{\mathrm{h}} \pm \\
0.03\end{array}$ & $\begin{array}{l}1.20^{\mathrm{fgh}} \pm \\
0.06\end{array}$ & $\begin{array}{l}4.37^{\mathrm{h}} \pm \\
0.08\end{array}$ & $\begin{array}{l}0.06^{\mathrm{g}} \pm \\
0.01\end{array}$ \\
\hline & & Dry & $\begin{array}{l}4.15^{\mathrm{g}} \pm \\
0.07\end{array}$ & $\begin{array}{l}167.40^{f} \pm \\
0.85\end{array}$ & $\begin{array}{l}112.60^{\mathrm{ijk}} \\
\pm 1.56\end{array}$ & $\begin{array}{l}0.09^{\mathrm{b}} \pm \\
0.01\end{array}$ & $\begin{array}{l}1.23^{\mathrm{fg}} \pm \\
0.10\end{array}$ & $\begin{array}{l}4.06^{\mathrm{kI}} \pm \\
0.06\end{array}$ & $\begin{array}{l}0.75^{\mathrm{d}} \pm \\
0.01\end{array}$ \\
\hline & \multirow{2}{*}{$10-20 \mathrm{~cm}$} & Wet & $\begin{array}{l}5.18^{f} \pm \\
0.03\end{array}$ & $\begin{array}{l}319.40^{\mathrm{b}} \pm \\
0.85\end{array}$ & $\begin{array}{l}343.00^{\mathrm{c}} \pm \\
0.28\end{array}$ & $\begin{array}{l}0.12^{\mathrm{fgh}} \pm \\
0.03\end{array}$ & $\begin{array}{l}0.84^{\mathrm{h}-\mathrm{k}} \pm \\
0.11\end{array}$ & $\begin{array}{l}4.23^{\mathrm{ij}} \pm \\
0.08\end{array}$ & $\begin{array}{l}0.01^{\mathrm{h}} \pm \\
0.00\end{array}$ \\
\hline & & Dry & $\begin{array}{l}3.36^{\mathrm{i}} \pm \\
0.06\end{array}$ & $\begin{array}{l}102.00^{\mathrm{h}} \pm \\
0.99\end{array}$ & $\begin{array}{l}92.10^{\mathrm{jkl}} \pm \\
0.42\end{array}$ & $\begin{array}{l}0.25^{\mathrm{efg}} \pm \\
0.08\end{array}$ & $\begin{array}{l}0.90^{g-j} \pm \\
0.08\end{array}$ & $\begin{array}{l}4.05^{\mathrm{kl}} \pm \\
0.05\end{array}$ & $\begin{array}{l}0.12^{f} \pm \\
0.00\end{array}$ \\
\hline & \multirow{2}{*}{$20-30 \mathrm{~cm}$} & Wet & $\begin{array}{l}2.90^{j} \pm \\
0.21\end{array}$ & $\begin{array}{l}235.80^{\mathrm{d}} \pm \\
47.66\end{array}$ & $\begin{array}{l}258.60^{\mathrm{de}} \\
\pm 5.66\end{array}$ & $\begin{array}{l}0.80^{\mathrm{d}} \pm \\
0.06\end{array}$ & $\begin{array}{l}1.42^{\mathrm{f}} \pm \\
0.06\end{array}$ & $\begin{array}{l}3.98^{\mathrm{kl}} \pm \\
0.03\end{array}$ & $\begin{array}{l}0.00^{\mathrm{h}} \pm \\
0.00\end{array}$ \\
\hline & & Dry & $\begin{array}{l}2.81^{\mathrm{j}} \pm \\
0.07\end{array}$ & $\begin{array}{l}116.00^{\text {gh }} \\
\pm 1.70\end{array}$ & $\begin{array}{l}88.30^{\mathrm{jkl}} \pm \\
16.12\end{array}$ & $\begin{array}{l}0.12^{\mathrm{fg}} \pm \\
0.01\end{array}$ & $\begin{array}{l}0.64^{\mathrm{i}-\mathrm{m}} \pm \\
0.11\end{array}$ & $\begin{array}{l}3.96^{1} \pm \\
0.14\end{array}$ & $\begin{array}{l}0.00^{\mathrm{h}} \pm \\
0.00\end{array}$ \\
\hline \multirow{6}{*}{ Valley } & \multirow{2}{*}{$0-10 \mathrm{~cm}$} & Wet & $\begin{array}{l}1.63^{\mathrm{k}} \pm \\
0.10\end{array}$ & $\begin{array}{l}256.80^{\text {cd }} \\
\pm 3.11\end{array}$ & $\begin{array}{l}187.20^{\mathrm{fgh}} \\
\pm 11.60 \\
\end{array}$ & $\begin{array}{l}0.20^{\mathrm{e}-\mathrm{h}} \pm \\
0.06\end{array}$ & $\begin{array}{l}0.76^{i-1} \pm \\
0.13\end{array}$ & $\begin{array}{l}6.00^{\mathrm{c}} \pm \\
0.10\end{array}$ & $\begin{array}{l}1.04^{\mathrm{bc}} \pm \\
0.06\end{array}$ \\
\hline & & Dry & $\begin{array}{l}5.33^{\mathrm{f}} \pm \\
0.10\end{array}$ & $\begin{array}{l}124.40^{\text {gh }} \\
\pm 3.68\end{array}$ & $\begin{array}{l}90.60^{\mathrm{jkl}} \pm \\
0.57\end{array}$ & $\begin{array}{l}0.26^{\mathrm{ef}} \pm \\
0.07\end{array}$ & $\begin{array}{l}0.81^{\mathrm{ijk}} \pm \\
0.04\end{array}$ & $\begin{array}{l}5.05^{\mathrm{f}} \pm \\
0.05\end{array}$ & $\begin{array}{l}1.14^{\mathrm{b}} \pm \\
0.02^{2}\end{array}$ \\
\hline & \multirow{2}{*}{$10-20 \mathrm{~cm}$} & Wet & $\begin{array}{l}1.64^{\mathrm{k}} \pm \\
0.11\end{array}$ & $\begin{array}{l}252.00^{\text {cd }} \\
\pm 0.57\end{array}$ & $\begin{array}{l}149.10^{\mathrm{hi}} \\
\pm 0.71\end{array}$ & $\begin{array}{l}0.16^{\mathrm{e}-\mathrm{h}} \pm \\
0.01\end{array}$ & $\begin{array}{l}0.49^{k-n} \pm \\
0.16\end{array}$ & $\begin{array}{l}5.70^{\mathrm{d}} \pm \\
0.10\end{array}$ & $\begin{array}{l}0.92^{\mathrm{c}} \pm \\
0.05\end{array}$ \\
\hline & & Dry & $\begin{array}{l}5.12^{f} \pm \\
0.16\end{array}$ & $\begin{array}{l}120.40^{\mathrm{gh}} \\
\pm 0.85\end{array}$ & $\begin{array}{l}57.10^{1} \pm \\
0.57\end{array}$ & $\begin{array}{l}0.29^{\mathrm{e}} \pm \\
0.03\end{array}$ & $\begin{array}{l}0.53^{\mathrm{j}-\mathrm{m}} \pm \\
0.04\end{array}$ & $\begin{array}{l}5.34^{\mathrm{e}} \pm \\
0.10\end{array}$ & $\begin{array}{l}0.89^{\mathrm{c}} \pm \\
0.01\end{array}$ \\
\hline & \multirow{2}{*}{$20-30 \mathrm{~cm}$} & Wet & $\begin{array}{l}1.64^{\mathrm{k}} \pm \\
0.03\end{array}$ & $\begin{array}{l}250.40^{\text {cd }} \\
\pm 0.85\end{array}$ & $\begin{array}{l}88.35^{\mathrm{jkl}} \pm \\
2.18\end{array}$ & $\begin{array}{l}0.11^{\text {gh }} \pm \\
0.03\end{array}$ & $\begin{array}{l}0.82^{\mathrm{ijk}} \pm \\
0.10\end{array}$ & $\begin{array}{l}5.45^{\mathrm{e}} \pm \\
0.05\end{array}$ & $\begin{array}{l}0.00^{\mathrm{h}} \pm \\
0.00\end{array}$ \\
\hline & & Dry & $\begin{array}{l}3.20^{\mathrm{i} \pm} \\
0.08\end{array}$ & $\begin{array}{l}106.00^{\mathrm{gh}} \\
\pm 0.99\end{array}$ & $\begin{array}{l}63.00^{\mathrm{kl}} \pm \\
0.71\end{array}$ & $\begin{array}{l}0.18^{\mathrm{e}-\mathrm{h}} \pm \\
0.06\end{array}$ & $\begin{array}{l}0.92^{\text {ghi }} \pm \\
0.08\end{array}$ & $\begin{array}{l}4.68^{g} \pm \\
0.02\end{array}$ & $\begin{array}{l}0.01^{\mathrm{h}} \pm \\
0.00\end{array}$ \\
\hline \multirow{6}{*}{ Control } & \multirow{2}{*}{$0-10 \mathrm{~cm}$} & Wet & $\begin{array}{l}9.10^{b} \pm \\
0.08\end{array}$ & $\begin{array}{l}301.10^{\mathrm{b}} \pm \\
0.85\end{array}$ & $\begin{array}{l}422.00^{\mathrm{b}} \pm \\
0.57\end{array}$ & $\begin{array}{l}0.81^{\mathrm{d}} \pm \\
0.08\end{array}$ & $\begin{array}{l}2.94^{\mathrm{e}} \pm \\
0.11\end{array}$ & $\begin{array}{l}6.52^{\mathrm{a}} \pm \\
0.06\end{array}$ & $\begin{array}{l}20.66^{\mathrm{a}} \pm \\
0.08\end{array}$ \\
\hline & & Dry & $\begin{array}{l}12.04^{\mathrm{a}} \pm \\
0.08\end{array}$ & $\begin{array}{l}380.00^{\mathrm{a}} \pm \\
1.13\end{array}$ & $\begin{array}{l}471.00^{\mathrm{a}} \pm \\
4.24\end{array}$ & $\begin{array}{l}1.46^{\mathrm{b}} \pm \\
0.10\end{array}$ & $\begin{array}{l}3.21^{\mathrm{e}} \pm \\
0.27\end{array}$ & $\begin{array}{l}6.55^{\mathrm{a}} \pm \\
0.14\end{array}$ & $\begin{array}{l}26.21^{\mathrm{a}} \pm \\
0.34\end{array}$ \\
\hline & \multirow{2}{*}{$10-20 \mathrm{~cm}$} & Wet & $\begin{array}{l}7.14^{\mathrm{d}} \pm \\
0.23\end{array}$ & $\begin{array}{l}310.00^{\mathrm{b}} \pm \\
12.73\end{array}$ & $\begin{array}{l}280.10^{\mathrm{d}} \pm \\
0.85\end{array}$ & $\begin{array}{l}0.92^{\text {cd }} \pm \\
0.08\end{array}$ & $\begin{array}{l}4.01^{\mathrm{d}} \pm \\
0.16\end{array}$ & $\begin{array}{l}6.48^{\mathrm{a}} \pm \\
0.08\end{array}$ & $\begin{array}{l}1.06^{\mathrm{bc}} \pm \\
0.07\end{array}$ \\
\hline & & Dry & $\begin{array}{l}9.20^{\mathrm{c}} \pm \\
0.07\end{array}$ & $\begin{array}{l}367.10^{\mathrm{b}} \pm \\
4.10\end{array}$ & $\begin{array}{l}316.00^{\mathrm{cd}} \\
\pm 13.86\end{array}$ & $\begin{array}{l}1.20^{\mathrm{a}} \pm \\
0.16\end{array}$ & $\begin{array}{l}4.40^{\mathrm{c}} \pm \\
0.03\end{array}$ & $\begin{array}{l}6.19^{\mathrm{b}} \pm \\
0.03\end{array}$ & $\begin{array}{l}1.15^{\mathrm{b}} \pm \\
0.09\end{array}$ \\
\hline & \multirow{2}{*}{$20-30 \mathrm{~cm}$} & Wet & $\begin{array}{l}4.03^{\text {gh }} \pm \\
0.13\end{array}$ & $\begin{array}{l}198.10^{\mathrm{e}} \pm \\
0.85\end{array}$ & $\begin{array}{l}200.00^{\mathrm{fg}} \\
\pm 2.83\end{array}$ & $\begin{array}{l}0.44^{\mathrm{c}} \pm \\
0.45\end{array}$ & $\begin{array}{l}5.82^{\mathrm{b}} \pm \\
0.01\end{array}$ & $\begin{array}{l}6.24^{\mathrm{b}} \pm \\
0.04^{-}\end{array}$ & $\begin{array}{l}0.00^{\mathrm{h}} \pm \\
0.00\end{array}$ \\
\hline & & Dry & $\begin{array}{l}5.16^{\mathrm{f}} \pm \\
0.14\end{array}$ & $\begin{array}{l}248.00^{\mathrm{cd}} \\
\pm 1.56\end{array}$ & $\begin{array}{l}224.00^{\mathrm{ef}} \\
\pm 1.70\end{array}$ & $\begin{array}{l}1.01^{\mathrm{c}} \pm \\
0.01\end{array}$ & $\begin{array}{l}6.53^{\mathrm{a}} \pm \\
0.14\end{array}$ & $\begin{array}{l}5.90^{\mathrm{c}} \pm \\
0.10\end{array}$ & $\begin{array}{l}0.00^{\mathrm{h}} \pm \\
0.00\end{array}$ \\
\hline
\end{tabular}

$a, b, c, d, e, f, g, h, i, j, k, l, m, n$ means in a column with different superscript are significantly different $(P<0.05)$. Values are mean \pm standard deviation of 3 replications; $O M=$ organic matter 
Table 2: Heavy metal concentration $(\mathrm{mg} / \mathrm{kg})$ in soil at Iva mine in wet and dry season

\begin{tabular}{|c|c|c|c|c|c|c|c|}
\hline Location & Depth & Season & $\mathrm{Ni}$ & $\mathrm{Pb}$ & As & $\mathrm{Fe}$ & $\mathrm{Cd}$ \\
\hline \multirow{6}{*}{ Crest } & \multirow{2}{*}{$0-10 \mathrm{~cm}$} & Wet & $28.01^{\mathrm{g}} \pm 0.03$ & $55.70^{\mathrm{d}} \pm 1.13$ & $0.00 \pm 0.00$ & $377.30^{\mathrm{j}} \pm 3.82$ & $5.02^{\mathrm{a}} \pm 0.11$ \\
\hline & & Dry & $20.05^{\mathrm{i}} \pm 0.21$ & $48.25^{\mathrm{e}} \pm 0.21$ & $0.00 \pm 0.00$ & $353.00^{\mathrm{k}} \pm 1.27$ & $0.11^{\mathrm{kl}} \pm 0.03$ \\
\hline & \multirow{2}{*}{$10-20 \mathrm{~cm}$} & Wet & $15.25^{\mathrm{j}} \pm 0.42$ & $45.30^{f} \pm 0.57$ & $0.00 \pm 0.00$ & $387.50^{\mathrm{i}} \pm 3.54$ & $2.87^{\mathrm{c}} \pm 0.13$ \\
\hline & & Dry & $10.05^{\mathrm{k}} \pm 0.78$ & $22.05^{\mathrm{m}} \pm 0.35$ & $0.00 \pm 0.00$ & $238.60^{\mathrm{n}} \pm 0.28$ & $0.07^{\mathrm{kl}} \pm 0.03$ \\
\hline & \multirow{2}{*}{$20-30 \mathrm{~cm}$} & Wet & $10.00^{\mathrm{k}} \pm 0.57$ & $38.10^{\mathrm{h}} \pm 0.28$ & $0.00 \pm 0.00$ & $402.80^{\mathrm{fg}} \pm 2.55$ & $1.01^{\mathrm{g}} \pm 0.13$ \\
\hline & & Dry & $6.10^{1} \pm 0.42$ & $29.40^{\mathrm{j}} \pm 0.85$ & $0.00 \pm 0.00$ & $218.00^{\circ} \pm 2.83$ & $0.48^{\mathrm{ij}} \pm 0.13$ \\
\hline \multirow{6}{*}{ Middle slope } & \multirow{2}{*}{$0-10 \mathrm{~cm}$} & Wet & $46.45^{\mathrm{d}} \pm 0.16$ & $37.50^{\mathrm{hi}} \pm 0.28$ & $0.00 \pm 0.00$ & $410.30^{\mathrm{e}} \pm 2.40$ & $0.49^{\mathrm{ij}} \pm 0.08$ \\
\hline & & Dry & $21.05^{\mathrm{i}} \pm 1.34$ & $30.01^{\mathrm{j}} \pm 1.40$ & $0.00 \pm 0.00$ & $238.60^{\mathrm{n}} \pm 1.56$ & $0.19^{\mathrm{k}} \pm 0.01$ \\
\hline & \multirow{2}{*}{$10-20 \mathrm{~cm}$} & Wet & $64.12^{\mathrm{b}} \pm 0.35$ & $65.04^{c} \pm 0.34$ & $0.00 \pm 0.00$ & $467.80^{c} \pm 3.11$ & $1.64^{\mathrm{e}} \pm 0.07$ \\
\hline & & Dry & $40.06^{\mathrm{e}} \pm 1.33$ & $43.60^{\mathrm{g}} \pm 1.56$ & $0.00 \pm 0.00$ & $392.70^{\mathrm{hi}} \pm 3.82$ & $0.04^{\mathrm{kl}} \pm 0.03$ \\
\hline & \multirow{2}{*}{$20-30 \mathrm{~cm}$} & Wet & $79.00^{\mathrm{a}} \pm 0.57$ & $81.60^{\mathrm{a}} \pm 0.57$ & $0.00 \pm 0.00$ & $498.20^{\mathrm{a}} \pm 2.55$ & $1.86^{\mathrm{d}} \pm 0.23$ \\
\hline & & Dry & $52.30^{\mathrm{c}} \pm 0.57$ & $69.70^{b} \pm 2.40$ & $0.00 \pm 0.00$ & $408.00^{\mathrm{ef}} \pm 2.83$ & $1.17^{\mathrm{f}} \pm 0.04$ \\
\hline \multirow{6}{*}{ Valley } & \multirow{2}{*}{$0-10 \mathrm{~cm}$} & Wet & $15.20^{\mathrm{j}} \pm 0.57$ & $36.65^{\mathrm{hi}} \pm 0.35$ & $0.00 \pm 0.00$ & $328.50^{1} \pm 2.12$ & $3.08^{\mathrm{b}} \pm 0.03$ \\
\hline & & Dry & $10.06^{\mathrm{k}} \pm 0.65$ & $23.85^{1} \pm 0.21$ & $0.00 \pm 0.00$ & $397.70^{\mathrm{gh}} \pm 0.42$ & $0.01^{\mathrm{kl}} \pm 0.01$ \\
\hline & \multirow{2}{*}{$10-20 \mathrm{~cm}$} & Wet & $23.50^{\mathrm{h}} \pm 0.37$ & $35.90^{\mathrm{i}} \pm 0.85$ & $0.00 \pm 0.00$ & $454.70^{\mathrm{d}} \pm 0.42$ & $0.74^{\mathrm{h}} \pm 0.07$ \\
\hline & & Dry & $10.05^{\mathrm{k}} \pm 0.49$ & $27.01^{\mathrm{k}} \pm 0.01$ & $0.00 \pm 0.00$ & $273.70^{\mathrm{m}} \pm 0.42$ & $0.08^{\mathrm{kl}} \pm 0.03$ \\
\hline & \multirow{2}{*}{$20-30 \mathrm{~cm}$} & Wet & $31.07^{\mathrm{f}} \pm 0.38$ & $26.10^{\mathrm{k}} \pm 0.28$ & $0.00 \pm 0.00$ & $490.00^{\mathrm{b}} \pm 5.66$ & $0.61^{\mathrm{hi}} \pm 0.04$ \\
\hline & & Dry & $23.13^{\mathrm{h}} \pm 0.33$ & $19.60^{\mathrm{n}} \pm 0.28$ & $0.00 \pm 0.00$ & $381.40^{\mathrm{j}} \pm 1.98$ & $0.41^{\mathrm{j}} \pm 0.07$ \\
\hline \multirow{6}{*}{ Control } & \multirow{2}{*}{$0-10 \mathrm{~cm}$} & Wet & $0.02^{\mathrm{m}} \pm 0.01$ & $1.48^{\circ} \pm 0.12$ & $0.00 \pm 0.00$ & $70.60^{r} \pm 0.57$ & $0.01^{\mathrm{kl}} \pm 0.00$ \\
\hline & & Dry & $0.02^{\mathrm{m}} \pm 0.01$ & $0.72^{\circ} \pm 0.04$ & $0.00 \pm 0.00$ & $43.00^{t} \pm 0.57$ & $0.00^{1} \pm 0.00$ \\
\hline & \multirow{2}{*}{$10-20 \mathrm{~cm}$} & Wet & $0.01^{\mathrm{m}} \pm 0.00$ & $1.01^{\circ} \pm 0.16$ & $0.00 \pm 0.00$ & $82.00^{\mathrm{q}} \pm 0.71$ & $0.00^{1} \pm 0.00$ \\
\hline & & Dry & $0.00^{\mathrm{m}} \pm 0.00$ & $0.40^{\circ} \pm 0.06$ & $0.00 \pm 0.00$ & $38.50^{\mathrm{t}} \pm 0.85$ & $0.00^{1} \pm 0.00$ \\
\hline & \multirow{2}{*}{$20-30 \mathrm{~cm}$} & Wet & $0.01^{\mathrm{m}} \pm 0.01$ & $0.26^{\circ} \pm 0.10$ & $0.00 \pm 0.00$ & $101.00^{\mathrm{p}} \pm 1.41$ & $0.00^{1} \pm 0.00$ \\
\hline & & Dry & $0.00^{\mathrm{m}} \pm 0.00$ & $0.22^{\circ} \pm 0.08$ & $0.00 \pm 0.00$ & $62.00^{\mathrm{s}} \pm 4.24$ & $0.00^{1} \pm 0.00$ \\
\hline
\end{tabular}

$a, b, c, d, e, f, g, h, i, j, k, l, m, n, o, p, q, r, s, t$, means in a column with different superscript are significantly different $(P<0.05)$. Values are mean \pm standard deviation of 3 replications

Table 3: Comparison of values obtained in this study with previous work at mine sites in Nigeria

\begin{tabular}{|c|c|c|c|c|}
\hline Heavy metals & $\begin{array}{l}\text { Levels obtained in } \\
\text { this study (mg/kg) }\end{array}$ & $\begin{array}{l}\text { Ranges of values } \\
(\mathrm{mg} / \mathrm{kg})\end{array}$ & Locations in Nigeria & Authors \\
\hline $\mathrm{Cd}$ & $0.01-3.06$ & $\begin{array}{l}28.8-126.0 \\
0.42-0.70 \\
26-210 \\
0.8-6.0\end{array}$ & $\begin{array}{l}\text { Enyigba, Ebonyi State } \\
\text { OdoIllesa, Osun State } \\
\text { Arufu, Benue State } \\
\text { Benue State }\end{array}$ & $\begin{array}{l}\text { Oti and Nwabue (2013) } \\
\text { Ekwue } \text { et al. } 2012 \\
\text { Adamu et al. (2011) } \\
\text { Adamu and Nganje (2010) }\end{array}$ \\
\hline $\mathrm{Ni}$ & $4.15-79.00$ & $\begin{array}{l}2.0-39.5 \\
6.34-17.4 \\
\end{array}$ & $\begin{array}{l}\text { Ishiagu, Ebonyi State } \\
\text { Osun State }\end{array}$ & $\begin{array}{l}\text { Eze and Chukwu (2011) } \\
\text { Adie and Etim (2012) }\end{array}$ \\
\hline $\mathrm{Fe}$ & $186.0-522.0$ & $102.17-181.08$ & Osun State & Mahboob (2001) \\
\hline As & $0.001-0.003$ & $\begin{array}{l}2.12-4.8 \\
8.0-18.0 \\
1.72-2.00 \\
\end{array}$ & $\begin{array}{l}\text { Enyigba, Ebonyi State } \\
\text { Benue State } \\
\text { OdoIllesa, Osun State }\end{array}$ & $\begin{array}{l}\text { Oti and Nwabue (2013) } \\
\text { Adamu and Nganje (2010) } \\
\text { Ekwue } \text { et al. (2012) }\end{array}$ \\
\hline $\mathrm{Pb}$ & $6.11-81.60$ & $\begin{array}{l}91.7-1,116.8 \\
11.5-27.7 \\
8.00-15.00 \\
\end{array}$ & $\begin{array}{l}\text { Enyigba, Ebonyi State } \\
\text { Osun State } \\
\text { OdoIllesa, Osun State }\end{array}$ & $\begin{array}{l}\text { Oti and Nwabue (2013) } \\
\text { Adie and Etim (2012) } \\
\text { Ekwue } \text { et al. (2012) }\end{array}$ \\
\hline
\end{tabular}

Table 4: Allowable limits of heavy metal concentrations in soil ( $\mathrm{mg} / \mathrm{kg}$ ) by various countries

\begin{tabular}{|l|l|l|l|l|l|l|l|}
\hline Heavy metals & Levels obtained in this study & Austria & Germany & France & Netherlands & Sweden & UK \\
\hline $\mathrm{Cd}$ & $0.01-3.06$ & $1-2$ & 1 & 2 & 0.5 & 0.4 & 3 \\
$\mathrm{Ni}$ & $4.15-79.00$ & $50-70$ & 50 & 50 & 15 & 30 & 75 \\
$\mathrm{~Pb}$ & $6.11-81.60$ & 100 & 70 & 100 & 40 & 40 & 300 \\
$\mathrm{Fe}$ & $186.0-522.0$ & NA & NA & NA & NA & NA & NA \\
$\mathrm{As}$ & $0.001-0.003$ & NA & NA & NA & NA & NA & NA \\
\hline
\end{tabular}

$N A=$ not available Source: $E C D G E(2010)$.

The concentration of $\mathrm{Pb}(81.60 \pm 0.57 \mathrm{mg} / \mathrm{kg})$ was highest in wet season at $20-30 \mathrm{~cm}$ middle slope of Iva mine (Table 2$)$ and this value was significantly $(\mathrm{P}<0.05)$ higher than $\mathrm{Pb}$ concentrations in control site $(1.46 \pm 0.23 \mathrm{mg} / \mathrm{kg})$ in wet and dry season. The high concentration of $\mathrm{Pb}$ at $20-30 \mathrm{~cm}$ middle slope was as a result of low content of organic matter in soil vis-à-vis the leaching of metals into the 
sub-layer of the soil during the wet season. Wide dispersion patterns are found in metal concentrations in soils, which may be due to transport from tailings, especially during the wet season (Chon et al., 2001), and flushes of dissolved ions in wet season runoff (acid mine drainage-AMD) are well known (Williams and Melack, 1991) to trigger the metal levels in soil, thus, elevated levels of metallic elements due to oxidation of sulphide minerals are frequently common characteristics of mine tailings (Vega et al., 2004). The concentration of $\mathrm{Pb}$ in soil at Iva mine $(81.60 \pm 0.57 \mathrm{mg} / \mathrm{kg})$ was about $76.91 \%(1.48 \pm 0.12 \mathrm{mg} / \mathrm{kg})$ higher than its $(\mathrm{Pb})$ value at the control site. Pokethitiyook et al. (2008) in their study reported that $\mathrm{Pb}$ concentration in soil from the land site was about 10 times higher than that from the pond site at the Bo Ngam lead mine, Thailand. The concentration of $\mathrm{Pb}(19.60 \pm 0.28$ $81.60 \pm 0.57 \mathrm{mg} / \mathrm{kg}$ ) in soil at Iva mine is lower than $21-484 \mathrm{mg} / \mathrm{kg}$ in soils at the Daduk Au-Ag-PbZn mine, Korea (Chon et al., 2001) but higher than $2.5-36.3 \mathrm{mg} / \mathrm{kg}$ in soils at Zacatecas mine, Mexico (González and González-Chávez, 2006).

$\mathrm{Ni}(79.00 \pm 0.57 \mathrm{mg} / \mathrm{kg})$ and $\mathrm{Cd}(5.02 \pm 0.11 \mathrm{mg} / \mathrm{kg})$ were observed to peak in wet season at 20-30 $\mathrm{cm}$ middle slope and 0-10 cm crest of Iva mine, respectively. Liang et al. (2003) opined that transfer through water runoff is the main vehicle of heavy metal transportation in soil. The $\mathrm{Ni}(79.00 \pm 0.57$ $\mathrm{mg} / \mathrm{kg})$ in soil at Iva mine was about $79.92 \%(0.02 \pm 0.00 \mathrm{mg} / \mathrm{kg})$ higher than its concentrations at control site while Cd in soil $(5.02 \pm 0.11 \mathrm{mg} / \mathrm{kg})$ at Iva mine was about $61.93 \%(0.01 \pm 0.00 \mathrm{mg} / \mathrm{kg})$ higher than its concentration at control site. The Ni $(6.10 \pm 0.42-79.00 \pm 0.57 \mathrm{mg} / \mathrm{kg})$ in soil at Iva mine is higher than $0.5-13.7 \mathrm{mg} / \mathrm{kg}$ in soils at Zacatecas mine, Mexico (González and GonzálezChávez, 2006). The Cd $(0.01 \pm 0.00-5.02 \pm 0.11 \mathrm{mg} / \mathrm{kg})$ in soil at Iva mine is higher than $0.34-2.12$ $\mathrm{mg} / \mathrm{kg}$ in China (SEPAC, 1995; Bai et al., 2008) $0.4-4.76 \mathrm{mg} / \mathrm{kg}$ in soils at the Daduk Au-Ag-Pb-Zn mine, Korea (Chon et al., 2001) and $0.3-3.3 \mathrm{mg} / \mathrm{kg}$ in soils at Zacatecas mine, Mexico (González and González-Chávez, 2006). The source of Cd in soil may be attributed to wastes such as spoil heaps and tailings deposited at the mine.

Logan and Miller (1983) suggested that soil contamination may be considered when concentrations of an element in soils were two-to-three times greater than the average background level. In this study, soils at the mined site is considered contaminated since $\mathrm{Pb}, \mathrm{Ni}$ and $\mathrm{Cd}$ concentrations in all the background (control) soil samples were significantly lower compared to their corresponding values in Iva mine. In Iva mined site, higher concentrations of the metals in soil occurred mostly at $20-30 \mathrm{~cm}$ (Table 2). At Iva mine, the concentrations of metals were higher at the middle slope than crest and valley, and this may be due to the topography of the site coupled with the leaching effect of rainfall due to low organic matter in soil. Large amounts of heavy metals present in tailings and associated soils provide a source for continuing dispersion down slope, and have led to various degree of contamination in soils (Chon et al., 2001).

\subsection{Conclusion}

The assessment of soil chemical characteristics at Iva mine show that coal mining affected the soil chemical characteristics of the mine site. Coal mining which involved vegetation removal affected negatively the soil organic matter and macro-nutrient content of soils around the coal mine site. It also increased soil acidity and elevated the levels of heavy metals in soil in the immediate environment of the mine site. The concentration of heavy metals in soil is high and its accumulation in plants could result to serious health risk to animals and man that depend on them (plants) for food. Therefore, effective remediation should be carried out at the mine site.

\section{References}

Adamu, C.I. and Nganje, T.N., (2010). Heavy metal contamination of surface soil in relationship to land use patterns: A case study of Benue State, Nigeria. Materials Sciences and Applications, 1(3), pp. $127-134$.

Adamu, C.I., et al. (2011). A Study of the Distribution pattern of heavy metals in surface soils around Arufu $\mathrm{Pb}-\mathrm{Zn}$ mine, Northeastern Nigeria, using factor analysis. Research Journal of Chemical Sciences, 1 (2), pp. 70-80. 
Adie, G.U. and Etim, E.U., (2012). Assessment of toxic heavy metal loading in topsoil samples within the vicinity of a limestone quarry in south western Nigeria. African Journal of Environmental Science and Technology, 6(8), pp. 322-330.

Agboola, A.A. and Fagbenro, J.A., (1985). Soil organic matter and its management in the humid tropics with particular reference to Nigeria. In: Proc. on soil fertility, soil tilth, and post clearing degradation in humid tropics, pp. 215-233.

Ademoroti, C.M.A., (1996). Heavy metals in air. Foludex Press, Ibadan, Nigeria.

Andersen, T.H. and Domsche, K.H., (1989). Ratios of microbial biomass carbon to total orgainic carbon in arable soils. Soil Biology and Biochemistry, 21(4), pp. 471-479.

Ando, M., Tadano, M., Asanuma, S., Matsushima, S., Wanatabe, T., et al. (1998). Health effects of indoor fluoride pollution from coal burning in China. Environmental Health Perspective, 106(5), pp. 239-244.

Asiegbu, J.E., (1989). Response of onion to lime and fertilizer $\mathrm{N}$ in a tropical ultisol. Tropical Agriculture, 66(2), pp. 161-166.

Bai, J., et al. (2008). Assessment of heavy metal contamination of roadside soils in Southwest China. Stochastic Environmental Research and Risk Assessment, 1, pp. 1-7.

Balogun, F.A., et al. (2003). Natural radioactivity associated with bituminous coal mining in Nigeria. Nuclear Instruments and Methods in Physics Research Section A, 505, pp. 444-448.

Bradshaw, A.D. and Chadwick, M.J., (1980). The restoration of land. Blackwell Scientific Publication, Oxford, England.

Brown, C.J. and Dey, A.K., (1975). The mineral and nuclear fuels of the India subcontinent and Burma. Oxford University Press, Delhi.

Chon, H., et al. (2001). Heavy metal contamination in the vicinity of the DadukAu-Ag-Pb-Zn mine in Korea. Applied Geochemistry, 16, pp. 1377-1386.

Derome, J. and Nieminen, T., (1998). Metal and macronutrient fluxes in heavy-metal polluted scots pine ecosystems in SW Finland. Environment Pollution, 103(2-3), pp. 219-228.

Diala, H.N.A., (1984). Review of some of the future problems and possible solution facing the Nigeria coal industry. Paper presented at the 20th annual conference: Nigeria Mining and Geoscience Society at the University of Nigeria, Nsukka, Nigeria.

Down, C.G., (1974). The relationship between colliery waste particle sizes and plant growth. Environmental Conservation, 1(4), pp. 29-40.

Ekere, N.R. and Ukoha, O.P., (2013). Heavy metals in street soil dusts of industrial market in Enugu, south east, Nigeria. International Journal of Physical Sciences, 8(4), pp. 175-178.

Ekklund, F., et al. (2001). Distribution with depth of protozoa, bacteria and fungi in soil profiles from three Danish forest sites. Soil Biology and Biochemistry, 33(4-5), pp. 475-481.

Ekwue, Y.A., et al. (2012). Assessment of metal contamination in soil and plants from abandoned secondary and primary goldmines in Osun State, Nigeria. Journal of Soil Science and Environmental Management, 3(11), pp. 262-274. 
Ezeh, H.N. and Chukwu, E., (2011). Small scale mining and heavy metals pollution of agricultural soils: The case of Ishiagu mining District, South eastern Nigeria. Journal of Geology and Mining Research, 3(4), pp. 87-104.

Fang, C., et al. (2005). Similar response of labile and resistant soil organic matter pools to changes in temperature. Nature, 433(7021), pp. 57-59.

Finkelman R.B., (2007). Health impacts of coal: facts and fallacies. Royal Swedish Academy of Sciences. Ambio, 36(1), pp. 103-105.

Gabriella, M.G. and Anton, A., (2005). Phytoremediation study; factors influencing heavy metal uptake of plants. ActaBiologica, 49(1-2), pp. 69-70.

Giachetti, G. and Sebastiani, L., (2006). Metal accumulation in poplar plant grown with industrial waste. Chemosphere, 64(3), pp. 446-454.

Gibson, D.J. and Risser, P.G., (1982). Evidence for the absence of ecotypic development in Andropogon virginicus (L.) on metalliferous mine wastes. New Phytologist, 92(4), pp. 589-599.

Gonzalez, R.C. and Gonzalez-Chavez, M.C.A., (2006). Metal accumulation in wild plants surrounding mining waste. Environ Pollut, 144(1), pp. 84-92.

Liang, T., et al. (2003). Transportation processes and rates of heavy metals in an artificial rainstorm runoff under different land use types. Chinese Journal of Applied Ecology, 14, pp. 1756-1760.

Logan, T.J. and Miller, R.H., (1983). Background levels of heavy metals in Ohio farm soil: Soil contamination analysis Research Circle Ohio. Agric Res Dev Ctr Wooster, 275, pp. 3-15.

Lu, R.K., (1999). Analytical methods of soil agrochemistry (in Chinese), China Agricultural Science and Technology Press, Beijing.

Mahboob, A.J., (2001). Heavy metal contamination of plants and soil in Itagunmodi gold deposit area of Osun State, Nigeria. In: Proceedings of the 27th Annual Conference of the Soil Science Society of Nigeria, November 2001, pp. 271-232.

Manzoni, S., et al. (2010). Stoichiometric controls on carbon, nitrogen, and phosphorus dynamics in decomposing litter. Ecological Monographs, 80(1), pp. 89-106.

Mbagwu, J.S.C. and Obi, M.E., (2003). Land degradation, agricultural productivity and rural poverty: Environmental implication. In: Proceedings of the 28th Annual Conference of the Soil Science Society of Nigeria at Umudike, Umuahia, Nigeria, 4-7th November, 2003, pp. 1-11.

National Mirror, Enugu Coal mines: Nigeria's abandoned huge resources by Dennis Agbo Thursday, February 28, 2013.

Nartey, V.K., et al. (2012). Studies on the contribution of fertilizers to heavy metal levels in soils and cocoa from some cocoa farms in the western region of Ghana. Journal of Natural Sciences Research, 2(8), pp. 111-120.

Nelson, D.W. and Sommers, L.E., (1982). Total carbon, organic carbon and organic matter, pp. 539577 in Methods of soil analysis, edited by A. L., R. H. Miller and D. R. Keeney, American Society of Agronomy, Madison.

Nelson, D.W. and Sommers L.E., (1972). Determination of total nitrogen in plant material. Agronomy Journal, 65(1), pp. 109-112.

Nicholson, F.A., et al. (2003). An inventory of heavy metals inputs to agricultural soils in England and Wales. Science Total Environment, 311, pp. 1-3. 
Novozamsky, I., et al. (1983). A novel digestion technique for multi-element plant analysis. Communications in Soil Science and Plant Analysis, 14, pp. 239-248.

Ogbonna, P.C. and Okezie, N., (2011). Heavy metal and macronutrient content of roadside soil and vegetation in Umuahia, Nigeria. Journal of Terrestrial and Aquatic Environmental Toxicology, 5(1), pp. 35-39.

Omenihu, A.A. and Ojimgba, A., (2008) Organic matter status of "acid sands" of southeastern Nigeria and its agricultural implications. Journal of Food and Fibre Production, 1, pp. 79-85.

Onweremadu, E.U., Mathews-Njoku, E.C., Nnadi, F.C., Anaeto, F.C., Ugwuoke, F.O., et al. (2008). Deterioration of soil organic components and adaptability of green fallows for soil fertility replenishment. Journal of American Science, 4(2), pp. 78-84.

Oti, W.J.O. and Nwabue, F.I., (2013). Heavy metals effect due to contamination of vegetables from Enyigba lead mine in Ebonyi State, Nigeria. Environment and Pollution, 2(1), pp. 19-26.

Oyodele, D.J., et al. (2008). Changes in soil properties and plant uptake of heavy metals on selected municipal solid waste dump sites in Ile-Ife, Nigeria. African Journal of Environmental Science and Technology, 3(5), pp. 107-115.

Porteus, A., (1985). Hazardous Waste Management Handbook. Butterworths and Co Publishers, United Kingdom.

Pokethitiyook, P., et al. (2008). Spatial and seasonal variations in lead content of plants colonizing the Bo Ngam lead mine, Thailand. Science Asia, 34, pp. 169-178.

Sarma, K., (2002). Impact of coal mining on vegetation: a case study in Jaintia Hill district of Meghalaya, India. M.Sc. Thesis, submitted to the International Institute for Geo-information Science and Earth Observation, Enschede, The Netherlands, pp. 85.

Shriadah, M.A., (1999). Heavy metals in mangrove sediments of the United Arab Emirates shoreline (Arabian Gulf). Water Air Soil Pollution, 116(3-4), pp. 523-534.

State Environmental Protection Administration of China, SEPAC (1995). Chinese Environmental Quality Standard for Soils (GB 15618-1995).

Steel, R.G.D. and Torrie, J.H., (1980). Principles and procedures of statistics: A biometric approach. McGraw-Hill, New York.

Taylor, J.P., et al. (2002). Comparison of microbial numbers and enzymatic activities in surface soils and subsoils using various techniques. Soil Biology and Biochemistry, 34(3), pp. 387-401.

The Tide, Coal as Potential Source of Energy by Admin, Thursday, February 28, 2013.

Ugiomoh, I.G. and Anyanwu, D.I., (2016). A study of soil properties in Machaerium lunatum environment of Niger Delta, Nigeria. European Journal of Physical and Agricultural Sciences, 4(2), pp. 20-30.

Vega, F.A., et al. (2004). Relationships between heavy metals content and soil properties in mine soils. Analytica Chimica Acta, 524, pp. 141-150.

Walkley, A. and Black, I.A., (1934). An examination of the Detgareff method for determining soil organic carbon, chronic titration method. Soil Sciences, 37, pp. 29-38. 
Williams, M.W. and Melack, J.M., (1991). Solute chemistry of snowmelt and runoff in an alpine basin, Sierra Nevada. Water Resources Research, 27(7), pp. 1575-1588.

Wong, J.W.C., et al. (1998). Acid-forming capacity of lead-zinc mine tailings and its implications for mine rehabilitation. Environmental Geochemistry and Health, 20(3), pp. 149-155. 